Analytical Chemistry Division

\title{
SEPARATION TECHNIQUES FOR THE CLEAN-UP OF RADIOACTIVE MIXED WASTE FOR ICP-AES/ICP-MS ANALYSIS
}

March 17, 1993

\author{
A. M. Swafford \\ J. M. Keller
}

Oak Ridge National Laboratory

Oak Ridge, Tennessee 37831

Prepared by the

OAK RIDGE NATIONAL LABORATORY

Oak Ridge, Tennessee 37831

managed by

MARTIN MARIETTA ENERGY SYSTEMS, INC.

for the

U.S. DEPARTMENT OF ENERGY

under contract DE-AC05-84OR21400 


\section{CONTENTS}

ABSTRACT 1

1. INTRODUCTION 1

1.1 Description of Waste Samples 2

1.2 Previous Studies of TOPO and 3

2. EXPERIMENTAL METHODS 7

2.1 Tracers 7

2.2 TOPO Extraction Procedure 7

2.3 TRU.Spec ${ }^{\mathrm{M}}$ Extraction Procedure 9

2.4 Analysis 9

2.4.1 Radioactive Samples 9 2.4.2 Non-radioactive Samples 10

$\begin{array}{lll}2.5 & \text { Quality Assurance } & 10\end{array}$

3. RESULTS AND DISCUSSION 11

3.1 Aluminum, Copper, Manganese, 11

3.2 Beryllium, Calcium, Magnesium, and Vanadium 11

3.3 Antimony 11

3.4 Arsenic, Barium, Cadmium, Chromium, 16

$\begin{array}{lll}3.5 & \text { Mercury } & 16\end{array}$

$\begin{array}{lll}3.6 & \text { Nickel } & 16\end{array}$

3.7 Selenium and Thallium 16

$\begin{array}{lll}3.8 & \text { Iron } & 17\end{array}$

3.9 Americium, Cerium, Cesium, Scandium, 17

3.10 Recovery Trends in the TOPO Extraction 17

4. PROCESS APPLICATIONS 19

$\begin{array}{lll}4.1 & \text { TOPO Extraction } & 19\end{array}$

4.2 TRU.Spec ${ }^{\mathrm{M}}$ Extraction 20

5. CONCLUSIONS 22

5.1 Summary 22

$\begin{array}{ll}5.2 & \text { Future Studies } \\ \end{array}$

6. REFERENCES 23 


\section{LIST OF FIGURES AND TABLES}

Figure $\quad \underline{\text { Page }}$

1 ICP Spectrum: Uranium Effects on Selenium Standard 5

2 ICP Spectrum: Thorium Effects on Arsenic Standard 5

Table $\quad \underline{\text { Page }}$

I Elements from the EPA Target Analyte List 3

II Primary Composition of MVSTs 4

III Tracers by Neutron Activation $\quad 8$

IV Recovery of EPA Target Analyte List Elements 12

From TOPO Extraction

V Recovery of EPA Target Analyte List Elements 13

From TRU.Spec ${ }^{\text {nd }}$ Extraction

VI Recovery of Other Elements Analyzed From 14

TOPO Extraction

VII Recovery of Other Elements Analyzed From $\quad 14$

TRU.Spec ${ }^{\text {TM }}$ Extraction

VIII Recovery of Tested Elements in Organic Phases 15

From TOPO Extraction

IX Maximum Loading Capacities of Actinides on TRU•Spec ${ }^{\text {TM }} 21$ 


\title{
SEPARATION TECHNIOUES FOR THE CLEAN-UP OF RADIOACTIVE MIXED WASTE FOR ICP-AES OR ICP-MS ANALYSIS
}

A.M. Swafford and J.M. Keller

\begin{abstract}
Two separation techniques were investigated for the clean-up of typical radioactive mixed waste samples requiring elemental analysis by Inductively Coupled Plasma - Atomic Emission Spectroscopy (ICP-AES) or Inductively Coupled Plasma - Mass Spectrometry (ICP-MS). These measurements frequently involve regulatory or compliance criteria which include the determination of elements on the EPA Target Analyte List (TAL). These samples usually consist of both an aqueous phase and a solid phase which is mostly an inorganic sludge. Frequently, samples taken from the waste tanks contain high lcvels of uranium and thorium which can cause spectral interferences in ICP-AES or ICP-MS analysis. The removal of these interferences is necessary to determine the presence of the EPA TAL elements in the sample. Two clean-up methods were studied on simulated aqueous waste samples containing the EPA TAL elements. The first method studied was a classical procedure based upon liquid-liquid extraction using trin-octylphosphine oxide (TOPO) dissolved in cyclohexane. The second method investigated was based on more recently developed techniques using extraction chromatography; specifically the use of a commercially available Eichrom TRU $\cdot S p e c{ }^{m}$ column. Literature on these two methods indicates the efficient removal of uranium and thorium from properly prepared samples and provides considerable qualitative information on the extraction behavior of many other elements. However, there is a lack of quantitative data on the extraction behavin r of elements on the EPA Target Analyte List. Experimental studies on these two methods consisted of determining whether any of the analytes were extracted by these methods and the recoveries obtained. Both methods produced similar results; the EPA target analytes were only slightly or not extracted. Advantages and disadvantages of each method were evaluated and found to be comparable. Additional experimental work with sludge matrices would be required to further evaluate the potential of each method for actual regulatory samples.
\end{abstract}

\section{INTRODUCTION}

The work described in this report is in support of environmental restoration programs at DOE facilities for characterization of mixed waste. It entails the evaluation of two clean-up 
methods which can be applied to waste tank samples for the analysis of the EPA target analytes by inductively coupled plasma- atomic emission spectroscopy (ICP-AES) or inductively coupled plasma-mass spectrometry (ICP-MS) and graphite furnace atomic absorption (GFAA). Evaluation of the methodology was based upon the application of tracers to follow recoveries of the EPA target analytes after a sample was subjected to cleanup methods. Solvent extraction using tri-n-octylphosphine oxide (TOPO) and extraction chromatography using an Eichrom Industries, Inc. (EIChroM) transuranic specific column (TRU.Spec ${ }^{m}$ ) were the clean-up methods applied. The results of each of these methods are described and compared in this report.

\subsection{Description of Waste Samples}

In many cases, radioactive waste samples are from underground storage tanks which contain both aqueous liquids and solids in the form of an inorganic sludge. The liquid phase is primarily concentrated sodium/potassium nitrate solutions at high $\mathrm{pH}$ (12-13) with high gamma-beta activity from caustic soluble fission products, mostly Cs-137. The sludge is typically a combination of hydroxides, carbonates, mixed- and hydrous- oxides, and various nitrate salts (the nitrates are mostly present in the interstitial liquid associated with the solids). The radioactivity present in the sludge includes caustic insoluble fission products (mostly lanthanides and strontium), ${ }^{137} \mathrm{Cs}$ adsorbed on the solids and present in the interstitial liquid and the actinides, which account for most of the alpha activity present in the waste tanks. Tanks often contain high levels of uranium and thorium which are either added for criticality control or are from various processing projects. The inorganic characterization of these waste samples includes the determination of the EPA target analytes (Table I) by ICP-AES or ICPMS. However, due to various spectral interferences, the high levels of uranium and/or thorium must be reduced prior to measurement by ICP-AES or ICP-MS. Table II summarizes the primary components observed in samples from six waste tanks, Melton Valley and Evaporator Facility Storage Tanks (MVST), at Oak Ridge National Laboratory. ${ }^{1}$ Ranges are listed in the Table II due to the large variation of compounds/elements typically found in waste tanks. This information represents typical compositions to be expected of samples from many radioactive waste storage tanks. 
Table I Elements from the EPA Target Analyte List

\begin{tabular}{ccc}
\hline Aluminum & Cobalt & Potassium \\
Antimony & Copper & Selenium \\
Arsenic & Iron & Silver \\
Barium & Lead & Sodium \\
Beryllium & Magnesium & Thallium \\
Cadmium & Manganese & Vanadium \\
Calcium & Mercury & Zinc \\
Chromium & Nickel & \\
\hline
\end{tabular}

The presence of high concentrations of uranium and/or thorium in the waste tank samples results in severe spectral interferences for many elements measured by ICP-AES or ICP-MS analysis. Figures 1 and 2 show ICP-AES spectra of analyte standards overshadowed by the large broad peaks from uranium and thorium. Also shown in the figures are spectra of TOPO extracted solutions in which the interferences no longer overshadow the peaks of the analyte standards. Liquid-liquid extraction using the TOPO method for removing uranium and thorium allows for the measurement of the analytes by ICP-AES as shown in the figures. The other method studied for removing uranium and thorium is extraction chromatography with the TRU.Spec ${ }^{\text {MM }}$ column. The TRU.Spec ${ }^{\mathrm{m} M}$ column method provides clean-up of the ICP emission spectra similar to the TOPO method.

\subsection{Previous Studies of TOPO and TRU.Spec Extractions}

The use of TOPO for the extraction of actinides is a well known classical method with considerable literature available. Most of these TOPO studies either centered around the extraction behavior of specific elements such as uranium and thorium or provided only qualitative extraction behavior on the remaining non-actinide elements. Although the previous studies provided excellent data on the recovery of uranium, thorium, and other actinides, the studies did not include quantitative recovery data for the elements left behind in the aqueous phase after extraction. Application of the TOPO extraction method for removing spectral interferences does not require that the actinide recovery be known, but the recovery of the elements remaining in the aqueous phase must be quantitative or at least known and consistent. 


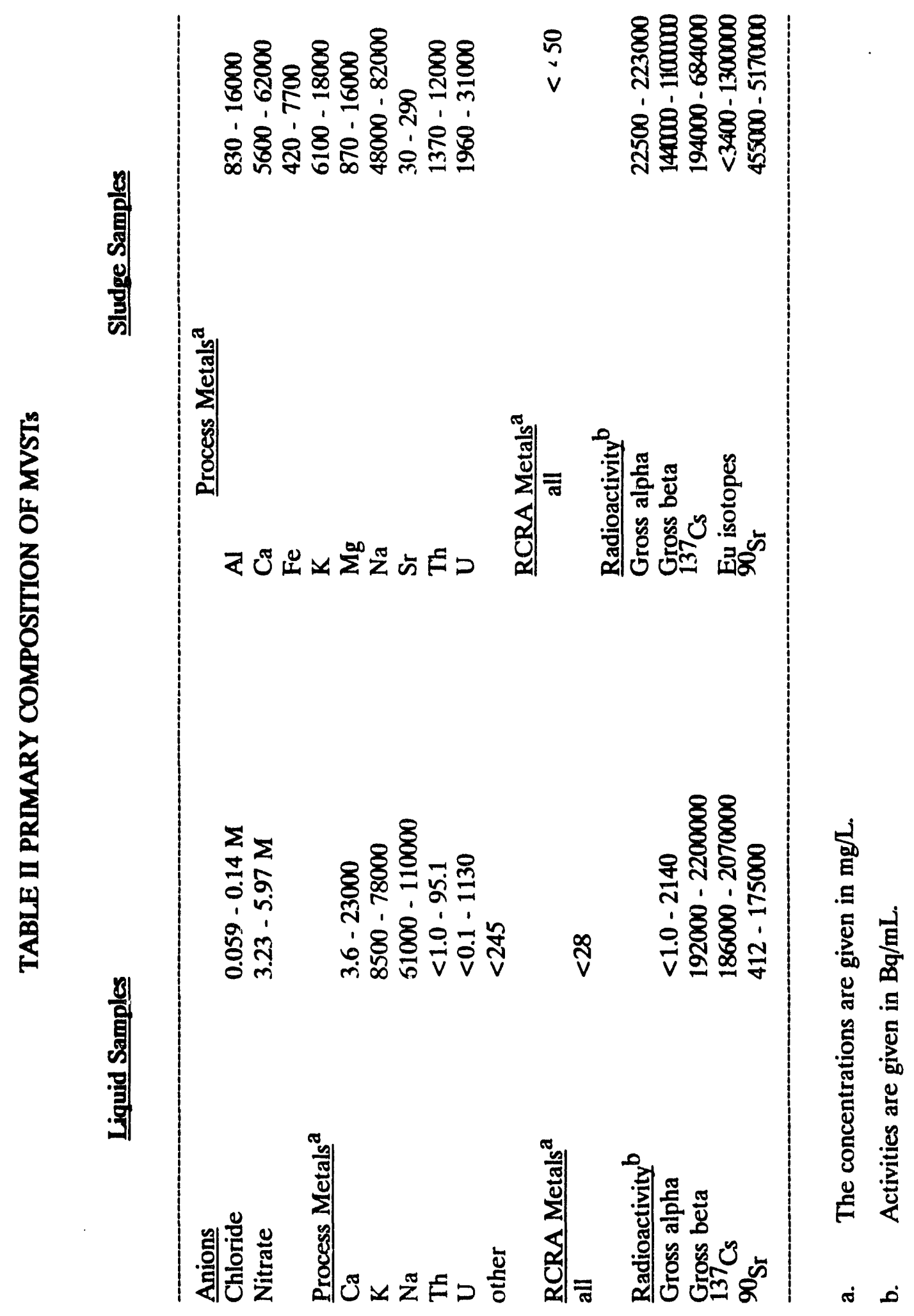


Figure 1

OAM OWO PAM. INA

ICP Spectrum: Uranium EHects on Selenium Standard (500 ug:m! Uranium)

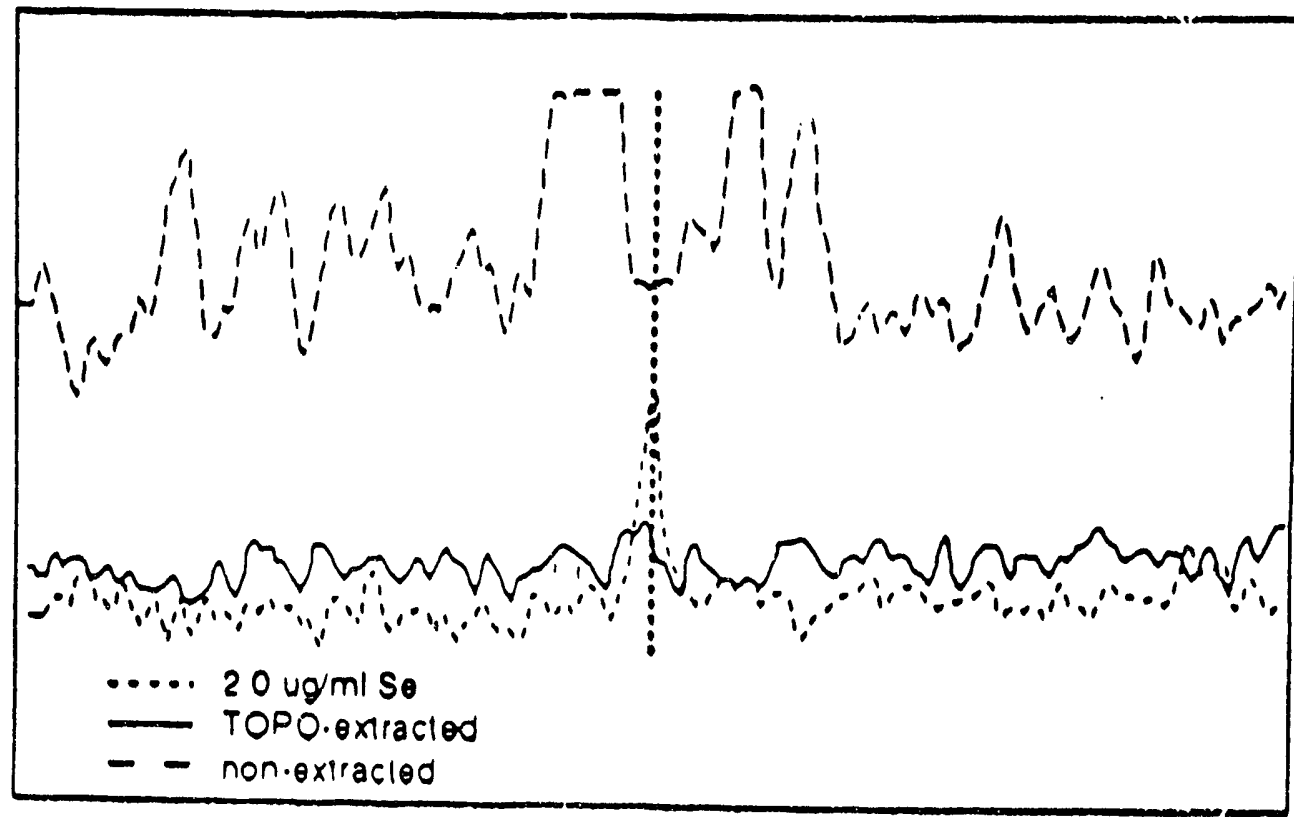

Figure 2

ICP Spectrum: Thorium Elfects on Arsenic Standard

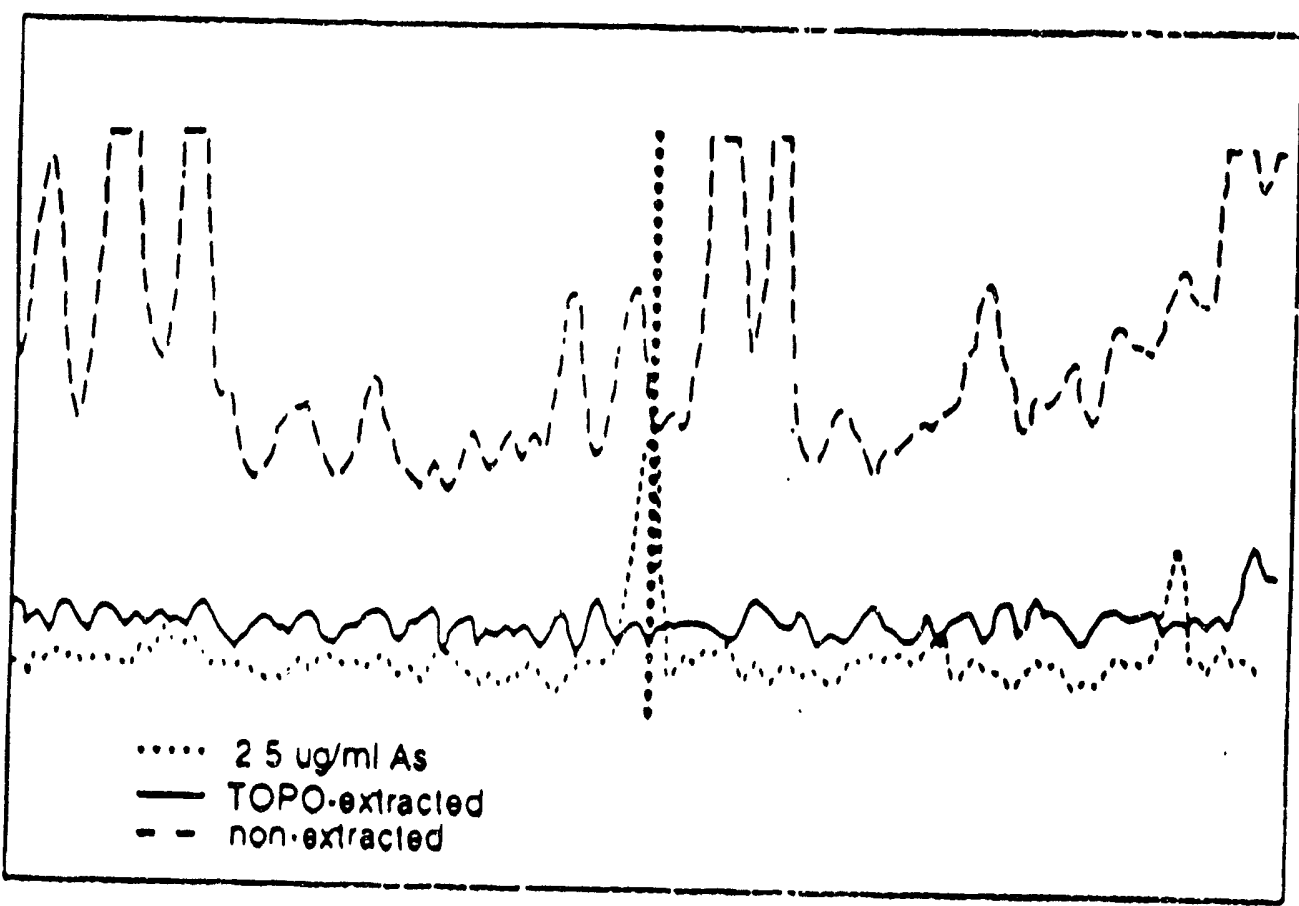


Much of the literature on TOPO originated from studies in the late 50's and 60's. The white waxy crystalline compound dissolved in a hydrocarbon diluent, preferably cyclohexane, was found to extract various elements from acidic solutions. One of its primary uses is the extraction of uranium and thorium. A representation of the extracted species is shown below: ${ }^{2}$

$$
\begin{gathered}
\mathrm{M}^{+\mathrm{n}_{\mathrm{Cl}}} \cdot 2(\mathrm{TOPO}) \\
\mathrm{M}^{+\mathrm{n}_{(}}\left(\mathrm{NO}_{3}\right)_{\mathrm{n}} \cdot 2(\mathrm{TOPO})
\end{gathered}
$$

The TRU.Spec ${ }^{\mathrm{m}}$ resin was developed by Argonne National Laboratories (ANL). This resin is available in either bulk quantities or as a pre-packed column ( $2 \mathrm{~mL}$ bed volume) from Eichrom Industries, P.O. Box 2399, Darien, IL 60559. The resin consists of an extractant octyl(phenyl)-N-N-diisobutyl-carbamoyl-methylphosphine oxide (CMPO) dissolved in tri-butyl phosphate (TBP) supported on an inert substrate (Amberlite ${ }^{\mathrm{m}}$ XAD-7, 80-160 $\mu \mathrm{m}$ polystyrene/divinyl benzene type material). Based on studies by ANL, the TRU.Spec ${ }^{\text {TM }}$ column provides efficient extraction of actininde and lanthanide elements at high acid concentrations, while eluting them under low acid conditions. The use of a synergistic solvent system, such as CMPO/TBP, is an example of the current direction of extraction technology. Shown below are examples of the CMPO extraction equilibria observed on the TRU・Spec ${ }^{\mathrm{m}}:^{3}$

$$
\begin{gathered}
\mathrm{Pu}^{4+}+4 \mathrm{NO}_{3}^{-}+2 \mathrm{E}-\mathrm{Pu}\left(\mathrm{NO}_{3}\right)_{4} \cdot \mathrm{E}_{2} \\
\mathrm{Am}^{3+}+3 \mathrm{NO}_{3}^{-}+3 \mathrm{E}-\mathrm{Am}\left(\mathrm{NO}_{3}\right)_{3} \cdot \mathrm{E}_{3} \\
\mathrm{UO}_{2}{ }^{2+}+2 \mathrm{NO}_{3}^{-}+2 \mathrm{E}-\mathrm{UO}_{2}\left(\mathrm{NO}_{3}\right)_{2} \cdot \mathrm{E}_{2}
\end{gathered}
$$

where E represents the extractant (CMPO).

Due to the lack of sufficient literature on the recovery of elements not highly extracted by these two methods and the need for the removal of high levels of uranium and/or thorium from waste samples for inorganic characterization, it was necessary to investigate the recoveries of various analytes of interest from these clean-up methods. 


\section{EXPERIMENTAL METHODS}

The experimental studies involved the preparation of simulated samples of appropriate matrices for each of the two extraction methods, addition of analyte tracers, and analysis before and after extraction. Simulated samples for the TOPO extraction consisted of three different nitric acid concentrations for studying recovery trends and a high nitrate matrix typical of waste samples. The samples prepared for the TRU.Spe. ${ }^{\mathbf{m}}$ extraction studies simply involved an aqueous solution at one molar nitric acid concentration. All of the samples were performed in triplicate, and averages and standard deviations of the results were determined.

\section{Tracers}

Recoveries of the EPA target analytes frosis ine TOPO and TRU-Spec extractions were determined by the use of radioactive and non-radioactive tracers. Stock solutions of these tracers were prepared with necessary dilutions for work throughout the study. Tracers of elements other than the EPA target analytes were present in some of the sources used to obtain the target analytes. These other elements were also evaluated in the extractions. Sources of the radioactive tracers included radioactive calibration standards from Amersham Corporation (2636 South Clearbrook Dr., Arlington Heights, IL 60005-4691), process samples of fission and activation products from transuranium (TRU) processing, and from neutron activation of salts and oxides of the analytes. Table III provides information on the materials used for neutron activation and the calculated activities of the radionuclides formed. Nonradioactive tracers were NIST calibration standards used for ICP analysis.

\subsection{TOPO Extraction Procedure}

Stock solutions of $1 \mathrm{M}, 2 \mathrm{M}$, and $3 \mathrm{M}$ nitric acid were prepared with each solution containing $0.4 \mathrm{M}$ sodium nitrate. Aliquots of each solution were sampled in triplicate and spiked with a tracer of analyte such that the total sample volume was $10 \mathrm{~mL}$. In some experiments the samples were spiked with several tracers to be evaluated together. In other experiments the tracers were analyzed individually. For radioactive tracer work this spike consisted of an activity to produce approximately 10,000 counts in 20-30 minutes by the particular counting technique to be used. This solution was analyzed by counting techniques for initial activity. The non-radioactive spiked samples contained $1-40 \mathrm{ug} / \mathrm{ml}$ of the tracer. For the non- 
radioactive work a control solution was also prepared and analyzed by ICP-AES to determine initial concentration before the extraction.

Table III TRACERS PRODUCED BY NEUTRON ACTIVATION

\begin{tabular}{|c|c|c|c|c|c|}
\hline ELEMENT & $\begin{array}{l}\text { NUCLIDE } \\
\text { FORMATION } \\
\text { REACTION }\end{array}$ & $\begin{array}{l}\text { CHEMICAL } \\
\text { FORM }\end{array}$ & $\begin{array}{l}\text { MASS OF } \\
\text { STARTING } \\
\text { MATERIAL }\end{array}$ & $\begin{array}{c}\text { EST. } \\
\text { GAMMAS } \\
\text { DER SEC. }\end{array}$ & $\begin{array}{l}\text { IRRADIATION } \\
\text { CONDITIONS }\end{array}$ \\
\hline Antimony & $\begin{array}{l}{ }^{121} S b(n, \gamma)^{12} S b \\
{ }^{12} S b(n, \gamma)^{121} S b\end{array}$ & $\mathrm{Sb}_{2} \mathrm{O}_{3}$ & $13 \mathrm{mg}$ & $\begin{array}{l}5 E+06 \\
2 E+05 \\
\end{array}$ & 2 \\
\hline Arsenic & ${ }^{19} \mathrm{As}(\mathrm{n}, \gamma)^{10} \mathrm{As}$ & $\mathrm{As}_{3} \mathrm{O}_{3}$ & $80 \mathrm{mg}$ & $4 E+07$ & 3 \\
\hline Chromium & ${ }^{30} \mathrm{Cr}(\mathrm{n}, y)^{3 !} \mathrm{Cr}$ & Cr metal & $10 \mathrm{mg}$ & $9 E+03$ & 3 \\
\hline Potassium & ${ }^{4} \mathrm{~K}(\mathrm{n}, \gamma)^{+2} \mathrm{~K}$ & $\mathrm{~K}_{2} \mathrm{CO}_{3}$ & $900 \mathrm{mg}$ & $2 E+06$ & 1 \\
\hline Scandium & ${ }^{10} S c(n, \gamma)^{\infty} S c$ & $\mathrm{Sc}_{2} \mathrm{O}_{3}$ & $5 \mathrm{mg}$ & $4 \mathrm{E}+05$ & 3 \\
\hline Selenium & ${ }^{75} \mathrm{Se}(\mathrm{n}, \gamma)^{16} \mathrm{Se}$ & Se powder & $10 \mathrm{mg}$ & $8 E+03$ & 3 \\
\hline Sodium & ${ }^{2} \mathrm{Na}(\mathrm{n}, \gamma)^{24} \mathrm{Na}$ & $\mathrm{NaNO}_{3}$ & $20 \mathrm{mg}$ & $8 E+05$ & 1 \\
\hline
\end{tabular}

Irradiation conditions:

1. Thermal flux $-5 \times 10^{13}$ (neutrons $/ \mathrm{m}^{2} \mathrm{~s}$ ) $\quad \mathrm{R}=200$

2. Thermal flux $-3.7 \times 10^{14}$ (neutrons $/ \mathrm{m}^{2} \mathrm{~s}$ ) $\mathrm{R}=30$

3. Thermal flux $-2 \times 10^{14}$ (neutrons $/ \mathrm{m}^{2} \mathrm{~s}$ ) $\mathrm{R}=30$ where $\mathbf{R}$ is the thermal/epithermal ratio irradiation time $=20$ seconds irradiation time $=20$ seconds irradiation time $=20$ seconds

* The estimated gamma activities per second were calculated using the equation below and the branching ratio of the most intense gamma energy of the nuclide. This was a rough estimate of the material activity before any dilutions were performed. The dilutions were based on this estimate and the efficiency of the detection apparatus to be used.

The equation for determining the activity produced after irradiating a sample for a specified time, $t$ is: ${ }^{4}$

$$
A(t)=N \sigma_{t h} \phi_{t h}\left(1-e^{-\lambda t}\right)+N\left(\phi_{t h} / R\right) I_{0}\left(1-e^{-\lambda t}\right)
$$

which reduces to the following equation:

$$
A(t)=N \phi_{t h}\left(1-e^{-\lambda t}\right)\left[\sigma_{t h}+\left(I_{0} / R\right)\right]
$$

where: $\mathrm{N}=$ number of atoms of the stable monitor nuclide $\lambda=$ decay constant of the nuclide produced

$\sigma_{\text {th }}=$ thermal neutron activation cross section $\phi_{\text {th }}=$ thermal neutron flux

$\mathrm{I}_{0}=$ activation cross section for resonance neutrons $\mathrm{R}=$ thermal to epithermal ratio 
A volume of $10 \mathrm{~mL}$ of $0.1 \mathrm{M}$ TOPO/cyclohexane was added to each of the spiked samples. The solutions were shaken by hand for 5 minutes and then allowed to separate. An aliquot ( $5 \mathrm{~mL}$ for radioactive solutions and $9 \mathrm{~mL}$ for non-radioactive solutions) of the aqueous phase was sampled and prepared for analysis either by counting techniques or ICP-AES. The organic phases of certain experiments chosen at random were sampled and analyzed the same way as the aqueous phases to determine the presence of the analytes.

\section{TRU-Spec Extraction Procedure}

An aliquot $(0.1-1 \mathrm{~mL})$ of a tracer stock solution was added to $5 \mathrm{~mL}$ of $4 \mathrm{M}$ nitric acid. This solution was loaded on an EIChroM TRU-Spec ${ }^{\mathrm{m}}$ column pre-conditioned by passing $15 \mathrm{~mL}$ of $4 \mathrm{M}$ nitric acid through it. This was followed by a wash of $15 \mathrm{~mL} 4 \mathrm{M}$ nitric acid. All of the effluent was collected and diluted to a known volume. An aliquot was then sampled and prepared for analysis by either counting techniques or ICP-AES for the determination of analyte recovery.

\subsection{Analysis}

\subsubsection{Radioactive Samples}

Gamma emitting radionuclides were counted by gamma spectroscopy on a Tennelec high purity germanium (HPGe) coaxial detector with a relative efficiency of $25 \%$ and a resolution of $1.85 \mathrm{KeV}$. If the sample volume was less than $10 \mathrm{~mL}$, dilute nitric acid or cyclohexane for organic samples was added to the sample to make a $10 \mathrm{~mL}$ volume. This was placed in a $20 \mathrm{~mL}$ scintillation vial which was counted for a time period sufficient to obtain at least 10,000 counts at either $0 \mathrm{~cm}$ or $3 \mathrm{~cm}$ from the detector. All counting data was based on relative measurements. The test samples were counted before and after extraction in the same geometry and for the same count time. Decay corrections were applied as necessary.

Due to the absence of measurable gamma emissions, nickel-63 and thallium-204 were analyzed by beta counting. The samples containing nickel- 63 were plated and counted on a Tennelec LB-1000 alpha/beta proportional counter for $20 \mathrm{~min}$. The thallium-204 samples were counted on a Packard 2550TR Liquid Scintillation Counter for $1 \mathrm{~min}$. using $15 \mathrm{~mL}$ of scintillation cocktail and less than $2 \mathrm{~mL}$ of sample. 


\subsubsection{Non-radioactive Samples}

The non-radioactive samples were analyzed by ICP-AES using a Spectroflame Model SAO-05 ICP Analytical Emission Spectrometer comparing visual peak heights of samples before and after extraction. No calibration was necessary since the recovery results were only relative to the initial sample concentration before extraction.

\section{Quality Assurance}

Quality control for this project was incorporated into the extraction procedure on the basis that the recovery results were referenced to the known initial activity or concentration of the spiked matrices before extraction. In the case of most of the radioactive samples, the solutions were counted before and after extraction, and relative recoveries were obtained. In other cases, such as for the short-lived nuclides and non-radioactive tracer work, a control containing equivalent tracer spikes was prepared but not subjected to the extraction procedure. Instead, this control was analyzed and compared with the spiked extracted sarnples to determine relative tracer recoveries.

Since the percent relative recovery was determined, well known instrument efficiencies and calibrations were not required. All recoveries were based upon the comparison of data obtained after extraction to standard solutions of the tracers measured prior to extraction. This would not affect recovery results of the elements. 


\section{RESULTS AND DISCUSSION}

Experimental results indicate that the EPA target analytes are only slightly extracted or not extracted by TOPO and TRU.Spec ${ }^{\mathrm{TM}}$ from nitric acid media. The recovery results of the analytes in nitric acid as well as corresponding standard deviations are presented in tables IV and V. Recovery results and deviations of other elements are listed in tables VI and VII. Table VIII presents results of the random testing of element recoveries in the organic phases from the TOPO extraction. The values listed in table VIII are mostly less than values due to the fact that the activity of the elements were below the minimum detectable level of the instrument.

\subsection{Aluminum, Copper, Manganese, Potassium, Sodium, and Zinc}

None of these elements were extracted by TOPO from nitric acid media or retained on the TRU.Spec ${ }^{\top M}$ column. This corresponded with literature findings on these elements. However, the recoveries obtained for potassium and sodium from the TRU.Spec extraction were slightly higher than those obtained in studies performed at Argonne National Laboratory. 5

\subsection{Beryllium, Calcium, Magnesium, and Vanadium}

These elements were also found to be non-extractable by TOPO ${ }^{6}$ and TRU.Spec ${ }^{\text {TM7 }}$ from nitric acid which agreed with the literature. However, the recoveries from the TOPO extraction for these elements were higher than $100 \%$. This bias was attributed to the possibility of entrained organics in the aqueous phase, thus affecting the particle size distribution produced in the nebulizer system for ICP analysis.

\subsection{Antimony}

According to experimental results it appears that antimony is partially extracted by TOPO from nitric acid media. ${ }^{8}$ However, literature indicated that antimony is extracted by TOPO only from chloride media. Experimental results did show that antimony was completely nonextracted by TRU.Spec ${ }^{\mathrm{TM}}$, but no literature was found to confirm or contradict this finding. 
TAble IV RECOVERY OF EPA TAL ELEMENTS FROM TOPO EXTRACTION

\begin{tabular}{|c|c|c|c|c|c|c|c|}
\hline \multirow[t]{3}{*}{ Element } & \multirow[t]{3}{*}{ Tracer } & \multicolumn{6}{|c|}{ AQUEOUS ACID SOLUTIONS } \\
\hline & & \multicolumn{2}{|c|}{$1 \mathrm{M} \mathrm{HNO}_{3}$} & \multicolumn{2}{|c|}{$2 \mathrm{M} \mathrm{HNO}$} & \multicolumn{2}{|c|}{$3 \mathrm{M} \mathrm{HNO}_{3}$} \\
\hline & & $\mathbf{R}$ & RSD & $\mathbf{R}$ & RSD & $\mathbf{R}$ & RSD \\
\hline Aluminum(III) & - & 102 & 1 & 100 & 1 & 99 & 2 \\
\hline Antimony(III) & ${ }^{123} \mathrm{Sb}$ & 88 & 3 & 86 & 6 & 88 & $<1$ \\
\hline Arsenic(ill) & ${ }^{\text {HAs }}$ & 98 & 4 & 90 & 2 & 93 & 3 \\
\hline Barium(II) & ${ }^{103} \mathrm{Ba}$ & 99 & 2 & 103 & 6 & 99 & 4 \\
\hline Beryllium(II) & - & 108 & 1 & 108 & 1 & 105 & 1 \\
\hline Cadmium(II) & ${ }^{100} \mathrm{Cd}$ & 99 & $<1$ & 104 & 2 & 102 & 3 \\
\hline Calciun(II) & - & 1Qi & 1 & 102 & 1 & 101 & 1 \\
\hline Chromium(III) & ${ }^{31} \mathrm{Cr}$ & 104 & 6 & 97 & 10 & 96 & 4 \\
\hline Cobalt(II) & ${ }^{\infty} \mathrm{Co}$ & 101 & $<1$ & 101 & 2 & 102 & 1 \\
\hline Copper(II) & - & 99 & 1 & 98 & 2 & 95 & 2 \\
\hline Iron(III) & NFe & 103 & 2 & 100 & $<1$ & 100 & $<1$ \\
\hline Lead(II) & $210 \mathrm{~Pb}$ & 95 & 9 & 89 & 1 & 106 & 5 \\
\hline Magnesium & - & 105 & 2 & 107 & 1 & 106 & 2 \\
\hline Manganese & ${ }^{M} \mathrm{Mn}$ & 101 & 3 & 102 & 4 & 102 & 1 \\
\hline Mercury(II) & ${ }^{20} \mathrm{Hg}$ & 90 & 19 & 100 & 18 & 111 & 5 \\
\hline Nickel(II) & ${ }^{\infty} \mathrm{Ni}$ & 91 & 3 & 88 & 5 & 85 & 4 \\
\hline Potassium(I) & ${ }^{8} \mathrm{~K}$ & 100 & 1 & 98 & 2 & 101 & $<1$ \\
\hline Selenium & rse & 100 & 5 & 99 & 5 & 98 & 7 \\
\hline Silver(I) & ${ }^{110 \mathrm{~m}} \mathrm{~A}_{8}$ & 102 & 2 & 102 & 1 & 99 & 2 \\
\hline Sodium(I) & ${ }^{2} \mathrm{Na}_{2}$ & 100 & 3 & 99 & 4 & 101 & 1 \\
\hline Thallium & 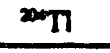 & 100 & 6 & 100 & 1 & 100 & 2 \\
\hline Vanadium(IV) & - & 97 & 2 & 107 & 1 & 108 & 2 \\
\hline Zinc(II) & ${ }^{*} \mathrm{Zn}$ & 96 & 1 & 102 & 2 & 100 & $<1$ \\
\hline
\end{tabular}

$R=$ average percent recovery of element in the aqueous phase. RSD = relative standard deviation based on three replicates. 
Table V RECOVERY OF EPA TAL ELEMENTS FROM TRU SPEC" EXTRACTION

\begin{tabular}{|c|c|c|c|}
\hline Element & $\begin{array}{l}\text { Radioactive } \\
\text { Tracer }\end{array}$ & $\begin{array}{c}\text { TRU-Spec } \\
\text { (ORNL) } \\
\text { 4M HNO, } \\
\text { \% Recovery (RSD) }\end{array}$ & $\begin{array}{c}\text { TRU-Spec } \\
\text { (ANL) } \\
2 \mathrm{M} \mathrm{HNO}_{3} \\
\% \text { Recovery }\end{array}$ \\
\hline Aluminum(III) & - & $101(9)$ & 100 \\
\hline Antimony(III) & ${ }^{124} \mathrm{Sb}$ & $100(<1)$ & NA \\
\hline Arsenic(III) & ${ }^{10} \mathrm{As}$ & $100(<1)$ & NA \\
\hline Barium(II) & ${ }^{13} \mathrm{Ba}$ & $94 \quad(2)$ & 100 \\
\hline Beryllium(Il) & - & 101 (11) & NA \\
\hline Cadmium(II) & ${ }^{109} \mathrm{Cd}$ & $104(5)$ & 100 \\
\hline Calcium(II) & - & $100(9)$ & 100 \\
\hline Chromium(III) & ${ }^{31} \mathrm{Cr}$ & $93 \quad(2)$ & 100 \\
\hline Cobalt(II) & ${ }^{\infty 0} \mathrm{Co}$ & $103(3)$ & 100 \\
\hline Copper(II) & - & $101(10)$ & 100 \\
\hline Iron(III) & ${ }^{30} \mathrm{Fe}$ & $96 \quad(6)$ & 100 \\
\hline Lead(II) & ${ }^{210} \mathrm{~Pb}$ & $108(6)$ & 100 \\
\hline Magnesium(II) & - & $99 \quad(10)$ & 100 \\
\hline Manganese & ${ }^{34} \mathrm{Mn}$ & $99 \quad(<1)$ & 100 \\
\hline Mercury(II) & ${ }^{20} \mathrm{Hg}$ & $101(19)$ & NA \\
\hline Nickel(II) & ${ }^{\infty} \mathrm{Ni}$ & $86 \quad(5)$ & 100 \\
\hline Potassium(I) & ${ }^{42} \mathrm{~K}$ & $95 \quad(6)$ & 82 \\
\hline Selenium & ${ }^{75} \mathrm{Se}$ & $97 \quad(2)$ & NA \\
\hline Silver(I) & ${ }^{110 m} \mathrm{Ag}$ & $96 \quad(4)$ & 100 \\
\hline Sodium(I) & ${ }^{24} \mathrm{Na}$ & $96 \quad(5)$ & 93 \\
\hline Thallium & $200 \mathrm{TI}$ & $99 \quad(1)$ & NA \\
\hline Vanadium(IV) & - & 99 (11) & NA \\
\hline Zinc(II) & ${ }^{w} \mathrm{Zn}$ & $97 \quad(2)$ & 100 \\
\hline
\end{tabular}


Table VI RECOVERY OF OTHER ELEMENTS ANALYZED FROM TOPO EXTRACTION

\begin{tabular}{|c|c|c|c|c|c|c|c|}
\hline \multirow[t]{3}{*}{ Element } & \multirow[t]{3}{*}{ Tracer } & \multicolumn{6}{|c|}{ AQUEOUS ACID SOLUTIONS } \\
\hline & & \multicolumn{2}{|c|}{$1 \mathrm{M} \mathrm{HNO}_{3}$} & \multicolumn{2}{|c|}{$2 \mathrm{M} \mathrm{HNO}_{3}$} & \multicolumn{2}{|c|}{$3 \mathrm{M} \mathrm{HNO}$} \\
\hline & & $\mathbf{R}$ & RSD & $\mathbf{R}$ & RSD & $\mathbf{R}$ & RSD \\
\hline Americium & ${ }^{211} \mathrm{Am}$ & 76 & 2 & 103 & 8 & 101 & 5 \\
\hline Cerium(III) & ${ }^{141} \mathrm{Ce}$ & sh & 7 & 101 & 1 & 101 & 3 \\
\hline Cesium & ${ }^{137} \mathrm{Cs}$ & 102 & 3 & 103 & 3 & 103 & 2 \\
\hline Scandium(III) & $\operatorname{cosc}$ & 26 & 5 & 52 & 3 & 65 & 7 \\
\hline Strontium & ${ }^{* S \mathrm{Sr}}$ & 99 & 4 & 106 & 5 & 101 & 7 \\
\hline $\operatorname{Tin}(\mathrm{TV})$ & ${ }^{113} \mathrm{Sn}$ & 76 & 3 & 84 & 4 & 87 & 8 \\
\hline Yttrium(III) & "Y & 90 & 2 & 99 & 4 & 100 & 3 \\
\hline
\end{tabular}

$R=$ average percent recovery of element in aqueous phase.

RSD = relative standard deviation based on chree replicates.

Table VII RECOVERY OF OTHER ELEMENTS ANALYZED FKOM TRU.Spec" EXTRACTION

\begin{tabular}{|c|c|c|}
\hline Element & $\begin{array}{l}\text { Radioactive } \\
\text { Tracer }\end{array}$ & $\begin{array}{c}\text { TRU-Spec } \\
\text { (ORNL) } \\
\text { 4M HNO, } \\
15 \mathrm{~mL} \\
\text { \% Recovery (RSD) }\end{array}$ \\
\hline Americium & ${ }^{201} \mathrm{Am}$ & 0 \\
\hline Cerium(III) & ${ }^{101} \mathrm{Ce}$ & 0 \\
\hline Cesium & ${ }^{13} \mathrm{Cs}$ & $105(<1)$ \\
\hline Scandium(III) & ${ }^{\infty} \mathrm{Sc}$ & 0 \\
\hline Strontium & ${ }^{\infty} \mathrm{Sr}$ & $84(10)$ \\
\hline $\operatorname{Tin}(\mathrm{V})$ & ${ }^{113} \mathrm{Sn}$ & $90(i)$ \\
\hline Yttrium(III) & ${ }^{*} Y$ & $19(7)$ \\
\hline
\end{tabular}


Table VIII RECOVERY OF TESTED ELEMENTS IN ORGANIC PHASES FROM TOPO EXTRACTION

\begin{tabular}{|c|c|c|c|c|}
\hline \multirow[t]{2}{*}{ Element } & \multirow[t]{2}{*}{ Tracer } & \multicolumn{3}{|c|}{ 0.1M TOPO/Cyclohexane } \\
\hline & & $1 \mathrm{M} \mathrm{HNO}_{3}$ & $2 \mathrm{M} \mathrm{HNO}_{3}$ & 3M HNO, \\
\hline Americium & ${ }^{2 n} \mathrm{Am}$ & 24 & 4 & $<3$ \\
\hline Arsenic & ${ }^{\gamma}$ As & $<5$ & $<3$ & $<3$ \\
\hline Barium & ${ }^{133} \mathrm{Ba}$ & $<1$ & $<1$ & 0 \\
\hline Cadmium & ${ }^{100} \mathrm{Cd}$ & $<2$ & $<2$ & $<2$ \\
\hline Cerium & ${ }^{101} \mathrm{Ce}$ & 17 & 3 & $<1$ \\
\hline Cesium & ${ }^{137} \mathrm{Cs}$ & $<1$ & $<2$ & $<1$ \\
\hline Chromium & ${ }^{\mathrm{si}} \mathrm{Cr}$ & 0 & 0 & 0 \\
\hline Cobalt & ${ }^{\infty} \mathrm{Co}$ & $<1$ & $<1$ & $<1$ \\
\hline Lead & ${ }^{210} \mathrm{~Pb}$ & 0 & 0 & 0 \\
\hline Mercury & ${ }^{20} \mathrm{Hg}$ & 31 & 9 & $<8$ \\
\hline Scandium & $\operatorname{los}_{\mathrm{Sc}}$ & 79 & 45 & 35 \\
\hline Selenium & ${ }^{75} \mathrm{Se}$ & 0 & 0 & 0 \\
\hline Silver & ${ }^{110 m} \mathrm{Ag}$ & $<1$ & $<1$ & $<1$ \\
\hline Strontium & "Sr & $<4$ & $<3$ & $<3$ \\
\hline Yttrium & my & $<15$ & $<3$ & $<1$ \\
\hline
\end{tabular}

- Less than values are listed for the majority of elements due to the low activity of the solutions which are below the minimum detectable level of thi defector. 


\subsection{Arsenic, Barium, Cadmium, Chromium, Cobalt, Lead, and Silver}

Recovery results of these elements indicated that they were not extracted by TOPO or TRU.Spec ${ }^{m}$ from nitric acid media. The organic phases from the TOPO extraction experiments involving these elements were also analyzed. This further confirmed their nonextractability by TOPO. Literature findings also supported these results with the exception of arsenic and barium. Literature was not found on the retention of arsenic by TRU.Spec ${ }^{\mathrm{TM}}$ nor on the extraction of barium by TOPO.

\subsection{Mercury}

Accurate quantitative results were not obtained for mercury from either extraction study due to low counting efficiency of this element as a result of short half-life and low standard activity. However, these extraction methods would not be required for the detection of mercury in regulatory samples due to the common practice of measuring mercury by cold vapor atomic absorption spectrometry.

\subsection{Nickel}

The experimental results on this element would indicate that it is partially extracted by TOPO and TRU.Spec ${ }^{\mathrm{TM}}$; however, literature for both of these methods states that nickel is not extracted. 9,10 The low recovery results obtained in this study are believed to be due to the method of analysis. Since Ni-63 does not have a gamma emitter, it was measured by beta counting on a proportional counter with a window detector. This produced inefficient results due to the difficulty in preparing reproducible plates for this type of counter. The organic phase from the TOPO extraction of nickel was not measured due to the high solids produced on the plates from the presence of TOPO. The evaluation of this element should be repeated using beta liquid scintillation counting.

\subsection{Selenium and Thallium}

Neither selenium nor thallium extractabilities were found in the literature. The experimental studies on these elements indicate that they are not extracted by TOPO or TRU.Spec ${ }^{\mathrm{M}}$ from nitric acid media. 


\subsection{Iron}

The sources of iron used in this experiment were from transuranium processing solutions which were expected to contain a mixture of $\mathrm{Fe}$ (II) and $\mathrm{Fe}$ (III). This did not present a problem in the TOPO extraction experiments. Iron recoveries in the aqueous phase were high. Literature indicates that $\mathrm{Fe}$ (II) is not extracted by TOPO, and that $\mathrm{Fe}$ (III) is only extracted by TOPO from chloride solutions. ${ }^{11}$ Problems were encountered however in the TRU.Spec ${ }^{m}$ studies on the process solutions. Recovery of iron was very low. After performing a series of experiments on $\mathrm{Fe}$ (II) and $\mathrm{Fe}$ (III) individually it was found that $\mathrm{Fe}$ (III) is retained on the column and $\mathrm{Fe}$ (II) is not retained. This required a reduction of iron to $\mathrm{Fe}$ (II) by titrating the process solution with $0.1 \mathrm{~N}$ ascorbic acid before introducing the sample to the TRU.Spec ${ }^{\mathrm{m} M}$ column. Studies were not performed on the matrix effects of ascorbic acid on ICP analysis.

\subsection{Americium, Cerium, Cesium, Scandium, Strontium, Tin, and Yttrium}

These elements are not part of the EPA target analyte list but were present in some of the source solutions. The results from the TOPO extraction experiments led to the conclusion that the elements are not extracted by TOPO from nitric acid media with the exception of americium, scandium, and tin. According to experimental results americium is partially extracted at $1 \mathrm{M} \mathrm{HNO}_{3}$ and tin and scandium are partially extracted at all three nitric acid concentrations tested. These results are further supported by analytical data on the organic phases in which significant amounts of scandium were observed at the three acid concentrations and americium at $1 \mathrm{M} \mathrm{HNO}_{3}$. The organic phases for the tin evaluation were not analyzed. The scandium results hold much importance due to its common use as an internal standard for ICP analysis. If scandium is desired to be used as an internal standard for a TOPO extracted sample, it should be added to the sample after the extraction procedure. The TRU.Spec ${ }^{n m}$ results indicated complete retention of americium, cerium, and scandium, partial extraction of strontium and yttrium, and slight or essentially no retention of cesium and tin. The use of scandium as an internal standard for a TRU.Spec ${ }^{\mathbf{M}}$ extracted sample would also require the addition of scandium to the sample after extraction.

\subsection{Recovery Trends in the TOPO Extraction}

Overall, none of the EPA target analytes showed significant changes in recovery from the 
TOPO extraction in increasing nitric acid concentration from 1 to 3 molar. Of the elements tested that were not EPA target analytes, three showed significant change in recovery from 1 to 3 molar nitric acid. Americium and cerium results indicated partial extraction by TOPO at $1 \mathrm{M} \mathrm{HNO}$ and no extraction at $2 \mathrm{M}$ and $3 \mathrm{M} \mathrm{HNO}_{3}$. Scandium extractablility decreased as acid concentration increased. 


\section{PROCESS APPLICATIONS}

The two extraction methods have produced similar recovery results of the EPA target analytes. Both have shown the potential for application to the clean-up of regulatory samples. The following sections discuss the application of each method to typical regulatory samples.

\subsection{TOPO Extraction}

TOPO has been commonly used for the extraction of uranium and thorium since the late 50 's with high success. Baserd on the results presented in this report it appears that TOPO could also be used successfully for the clean-up of regulatory samples for EPA target analyte measurements. There are numerous advantages to using this method as a clean-up tool. Due to the common use of TOPO, much literature is available. Literature states that 14-23 $\mathrm{mg}$ of thorium and $40 \mathrm{mg}$ of uranium can be extracted by $0.5 \mathrm{mmole}$ of TOPO which indicates that low concentrations of TOPO would be effective on the removal of uranium and thorium from waste samples. ${ }^{12}$ The method is also time efficient with a 5 minute extraction time producing successful removal of uranium and thorium as indicated in literature. TOPO is commercially available and can be applied to large scale processes. One of the disadvantages, however, is the production of organic waste which requires proper disposal. Another disadvantage of the method is the inability of TOPO to remove the majority of alpha emitters which may be present in waste, thereby complicating additional sample handling due to containment requirements. This method is also dependent on acid type and concentration which limits flexibility. The type of acid used or present and its concentration can affect the extractability of certain elements and the effects differ for individual elements.

One possibility for reducing organic waste in TOPO extractions would be to apply TOPO to extraction chromatography. Much literature is available on chromatographic columns of TOPO and indicates the preparation of the columns with many different supports such as cellulose, glass beads, polyethylene, and polyfluoroethylene. ${ }^{13}$ The extraction capabilities and limitations of TOPO on a column should parallel those of solvent extraction using TOPO. However, the application of TOPO to extraction chromatography may not produce any 
advantages over the TRU.Spec ${ }^{m}$ column.

\subsection{TRU.Spec ${ }^{\mathrm{m} M}$ Extraction}

Extraction chromatography using the TRU $\bullet S p e c{ }^{m}$ column is a more recent application for sample clean-up and purification. The available literature on this material stems from studies performed at Argonne National Laboratory (ANL) which discusses the successful separation of actinindes from complex solutions. These separations are dependent upon not exceeding the loading capacity of the columns. Table IX lists the theoretical maximum loading capacities of common actinides on the TRU.Spec ${ }^{\mathrm{TM}}$ column. Literature recommends a working capacity of $10-20 \%$ of the maximum loading capacity to minimize actinide loss. ${ }^{14}$ However, if recovery of the actinides is not necessary, and only separetion from the actinides is desired, $80-90 \%$ of the maximum loading capacity could be applied to the column. The ANL experimental studies also demonstrated that with higher levels of nitric acid, minimal extraction of the EPA target analytes was observed. This suggested the possible application of the TRU.Spec ${ }^{\text {mM }}$ columns for the clean-up of regulatory samples.

An advantage to the use of extraction chromatography is a significant reduction of organic waste compared to liquid-liquid extraction. Extraction chromatography generates solid waste which generally has less involved disposal requirements. Another advantage of using the TRU.Spec ${ }^{n k}$ is the high break through volumes for uranium and thorium associated with the column. Experimental studies have shown that as much as $200 \mathrm{ml}$ of $4 \mathrm{M} \mathrm{HNO}$ can be passed through the column without removal of uranium and only slight removal of thorium. These two elements are only efficiently removed from the column with an oxalate matrix. Other advantages include the removal of actinides and lanthanides resulting in an alpha free effluent, cost effectiveness, and the ability to automate the procedure which reduces dose to personnel. And unlike TOPO, TRU.Spec ${ }^{\boldsymbol{N}}$ is fairly insensitive to acid concentration; the concentration can range from $2-6 \mathrm{M} \mathrm{HNO}_{3}$ and still produce efficient results. ${ }^{15}$

Disadvantages of the method include the need for more detailed information and the limitation to small scale processes. More studies on element behavior, effects of salts on loading capacity, and possible interferences are needed to increase efficiency of the method. 
The method can only be eff.uently applied to small scale due to several factors. The procedure for the TRU.Spec ${ }^{\mathrm{TM}}$ extraction is also more time consuming than that for the TOPO extraction; gravitational flow rates can range from $0.5 \mathrm{~mL}-1.5 \mathrm{~mL}$ per minute based upon experimental observations.

Table IX. MAXIMUM LOADING CAPACTTIFS OF ACTINIDES ON TRU.SPEC ${ }^{\text {m }}$

\begin{tabular}{|c|c|c|c|c|c|}
\hline $\begin{array}{l}\text { VALENCE } \\
\text { NUMBER }\end{array}$ & NUCLIDE & $\begin{array}{c}\text { CAPACITY } \\
\mu \mathrm{mole} / \mathrm{mL}\end{array}$ & $\begin{array}{l}\text { CAPACITY } \\
\text { mg/column }\end{array}$ & $\begin{array}{l}\text { ACTIVITY } \\
\text { Ci/column }^{*}\end{array}$ & $\begin{array}{l}\text { ACTIVITY } \\
\text { Bq/column }\end{array}$ \\
\hline \multirow[t]{3}{*}{ (III) } & ${ }^{241} \mathrm{Am}$ & 38 & 18.3 & 6.28 E-02 & $2.32 \mathrm{E}+09$ \\
\hline & ${ }^{244} \mathrm{Cm}$ & 38 & 18.5 & $1.50 \mathrm{E}+00$ & $5.55 E+10$ \\
\hline & ${ }^{252} \mathrm{Cf}$ & 38 & 19.2 & $1.03 \mathrm{E}+01$ & $3.81 E+11$ \\
\hline \multirow[t]{6}{*}{ (IV) } & ${ }^{229} \mathrm{Th}$ & 56 & 25.7 & 5.46 E-03 & $2.02 \mathrm{E}+08$ \\
\hline & ${ }^{228} \mathrm{Th}$ & 56 & 25.5 & $2.09 \mathrm{E}+01$ & $7.75 \mathrm{E}+11$ \\
\hline & ${ }^{232} \mathrm{Th}$ & 56 & 25.0 & 2.86 E-09 & $1.06 \mathrm{E}+02$ \\
\hline & ${ }^{238} \mathrm{Pu}$ & 56 & 26.7 & 4.56 E- 01 & $1.69 \mathrm{E}+10$ \\
\hline & ${ }^{239} \mathrm{Pu}$ & 56 & 26.8 & $1.66 \mathrm{E}-0.3$ & $6.14 E+07$ \\
\hline & $240 \mathrm{Pu}$ & 56 & 26.9 & $6.10 \mathrm{E}-03$ & $2.26 \mathrm{E}+08$ \\
\hline \multirow{2}{*}{$\mathrm{UI}_{2}^{(\mathrm{VI})}+2$} & ${ }^{238} \mathrm{U}$ & 56 & 26.7 & 8.96 E-09 & $3.31 \mathrm{E}+02$ \\
\hline & $235_{U}$ & 56 & 26.3 & 5.69 E-08 & $2.10 \mathrm{E}+03$ \\
\hline
\end{tabular}

*Values based on $2 \mathrm{~mL}$ bed volume per column. 


\section{CONCLUSIONS}

\subsection{Summary}

In conclusion, experimental results indicate that either separation technique, solvent extraction using TOPO or extraction chromatography using TRU・Spec ${ }^{\mathbf{m}}$, could be used for the clean-up of regulatory samples, and depending on the specific application, one method may seem more advantageous over another. Advantages and disadvantages of each method have been discussed in section 4 . of this report. Both methods are evaluated in the literature on the effective removal of uranium and thorium from nitric acid solutions. The capacities of each method for extracting uranium and thorium are indicated in section 4 and are found to be comparable. This report also shows that neither method extracts the EPA target analyte list elements from nitric acid media. This would allow for successful determination of the analytes by ICP-AES or ICP-MS without interference from uranium and thorium. However, this may not be the case for regulatory samples containing high levels of chloride. Chloride forms complexes with many metals and could either interfere with the extraction of uranium and thorium or prevent the recovery of the other elements of interest. These chloride interferences could be observed in either of the sample clean-up methods discussed. In some cases the presence of chloride may result in undesired extraction such as the case with antimony and iron(III) in the TOPO extraction. As indicated in section 3 antimony and iron(III) are extracted by TOPO in the presence of chloride. If high levels of chloride are suspected in a sample, the sample should be evaporated 3-4 times with 4-5 $\mathrm{N} \mathrm{HNO}_{3}$ to convert chloride complexes to nitrate complexes.

\section{$5.2 \quad$ Future Studies}

Several areas of study have been considered for further experimental work on the clean-up of regulatory samples using TOPO and the TRU.Spec ${ }^{\mathbf{m}}$. Further experiments are planned for determining recoveries of the analytes using tracers in simulated sludge samples containing uranium and thorium. Another area of study is to apply TOPO to a column and evaluate the recoveries of the analytes, also using tracers. Kinetics studies of pressurized column chromatography are planned for the TRU.Spec ${ }^{\mathrm{m}}$ column. 


\section{REFERENCES}

1. M.B. Sears, J.L. Botts, et. al., Sampling and Analysis of Radioactive Liquid Wastes and Sludges in the Melton Valley and Evaporator Facility Storage Tanks at ORNL, ORNL/TM-11652,September 1990, pp. 36-43.

2. J.C. White and W.J. Ross, Separations by Solvent Extraction with Tri-noctylphosphine Oxide, U.S. Atomic Energy Commission, NAS-NS 3102, February 1961, pp. 1-3.

3. E.P. Horwitz, R. Chiarizia, M.L. Dietz, H. Diamond and D. Nelson Separation and Preconcentration of Actinides from Acidic Media by Extraction Chromatography, Anal. Chim. Acta (in press).

4. W.S. Lyon, Jr., F.F. Dyer, et. al., Guide to Activation Analysis, Robert E. Krieger Publishing Co., Huntington, NY, 1972, p.18.

5. E.P. Horwitz, R. Chiarizia, M.L. Dietz, H. Diamond and D. Nelson Separation and Preconcentration of Actinides from Acidic Media by Extraction Chromatography, Anal. Chim. Acta (in press).

6. J.C. White and W.J. Ross, Separations by Solvent Extraction with Tri-noctylphosphine Oxide, U.S. Atomic Energy Commission, NAS-NS 3102, February 1961, pp. 8 and 21.

7. E.P. Horwitz, R. Chiarizia, M.L. Dietz, H. Diamond and D. Nelson Separation and Preconcentration of Actinides from Acidic Media by Extraction Chromatography, Anal. Chim. Acta (in press).

8. J.C. White and W.J. Ross, Separations by Solvent Extraction with Tri-noctylphosphine Oxide, U.S. Atomic Energy Commission, NAS-NS 3102, February 1961, p. 23.

9. J.C. White and W.J. Ross, Separations by Solvent Extraction with Tri-noctylphosphine Oxide, U.S. Atomic Energy Commission, NAS-NS 3102, February 1961, p. 35.

10. E.P. Horwitz, R. Chiarizia, M.L. Dietz, H. Diamond and D. Nelson Separation and Preconcentration of Actinides from Acidic Media by Extraction Chromatography, Anal. Chim. Acta (in press).

11. J.C. White and W.J. Ross, Separations by Solvent Extraction with Tri-noctylphosphine Oxide, U.S. Atomic Energy Commission, NAS-NS 3102, February 1961, p. 33.

12. J.C. White and W.J. Ross, Separations by Solvent Extraction with Tri-noctylphosphine Oxide, U.S. Atomic Energy Commission, NAS-NS 3102, February 1961, pp. $42 \& 45$. 
13. T. Braun and G. Ghersini, Extraction Chromatography, Akadémiai Kiadó, Budapest, 1975, p.108.

14. E.P. Horwitz, R. Chiarizia, M.L. Dietz, H. Diamond and D. Nelson Separation and Preconcentration of Actinides from Acidic Media by Extraction Chromatography, Anai. Chim. Acta (in press).

15. E.P. Horwitz, R. Chiarizia, M.L. Dietz, H. Diamond and D. Nelson Separation and Preconcentration of Actinides from Acidic Media by Extraction Chromatography, Anal. Chim. Acta (in press). 


\section{INTERNAL DISTRIBUTION}
1. J. T. Bell
2. R. N. Ceo
3. F. F. Dyer
4. J. M. Giaquinto
5. D. C. Glasgow
6. W. H. Griest
7-11. J. M. Keller
12. R. C. Mason
13. C. D. Parks
14. L. Robinson
15. S. M. Robinson
16. T. Ross

17. R. L. Schenley

18. C. B. Scott

19. M. B. Sears

20. W. D. Shults

21. J. R. Stokely

22-42. A. M. Swafford

43. J. W. Wade

44. Central Research Library

45-46. Laboratory Records

47. ORNL Patent Section

48. Document Reference Section

49. L a b R e c ord s Department-RC 


\section{EXTERNAL DISTRIBUTION}

50. G. Bentley, Los Alamos National Laboratory, P.O. Box 1663, Los Alamos, NM 87545.

51. D. C. Bogen, Director of Analytical Chemistry Division, U.S. Department of Energy, 376 Hudson Street, New York, NY 10014.

52. A. S. Boparai, Group Leader of Organic Analysis Group, Chemical Technology Division, Argonne National Laboratory, 9700 South Cass Avenue, CMT/205, Argonne, IL 60439-4837.

53. J. Crain, Chemical Technology Division, Argonne National Laboratory, 9700 South Cass Avenue, Argonne, IL 60439-4837.

54. M. D. Erickson, Associate Director, Research and Development, Program Coordination Office, Argonne National Laboratory, 9700 South Cass Avenue, CMT/205, Argonne, IL 60439-4837.

55. N. W. Girvin, Pacific Northwest Laboratories, Battelle Boulevard, Richland, WA 99352.

56. S. C. Goheen, Senior Research Scientist, Chemical Sciences Department, Materials and Chemical Sciences Center, Pacific Northwest Laboratories, Battelle Boulevard, Richland, WA 99352.

57. J. T. Harvey, Program Technical Director, Radiochemistry and Mixed Waste, International Technology Corporation, Regional Office, 312 Directors Drive, Knoxville, TN 37923.

58. E. Hoppe, Pacific Northwest Laboratories, Battelle Boulevard, Richland, WA 99352.

59. D. I. Hunter, Manager, General Laboratories, Rocky Flats Plant, North American Space Operations, Rockwell International Corporation, P.O. Box 464, Golden, CO 80402-0464.

60. C. Leibman, Environmental Chemistry Division, Los Alamos National Laboratory, P.O. Box 1663, Los Alamos, NM 87545.

61. B. Lesnik, U. S. Environmental Protection Agency, Office of Solid Waste, Methods Section, OS-331, 401 M Street, South West, Washington, D. C. 20460.

62. L. Lewis, Analytical Chemistry Division, Westinghouse Idaho Nuclear, P.O. Box 4000, Idaho Falls, ID 83402.

63. V. Lloyd, Environmental Protection Agency/NAREL, 1504 Avenue A, Montgomery, AL 36115-2601.

64. J. J. McCown, Westinghouse Hanford Company, P.O. Box 1970, Richland WA 99352.

65. S. G. Metcalf, Principal Scientist, Analytical/Organic Chemistry, Process and Analytical Laborrtories, Westinghouse Hanford Company, T6-50, P.O. Box 1970, Richland, WA 99352.

66. S. Morton, Senior Scientist, Radiological and Environmental Sciences Laboratory, U. S. Department of Energy, 785 DOE Place, Idaho Falls, ID 83402.

67. J. P ppiti, U. S. Department of Energy, Office of Technology Development, Laboratory Management Division (EM-532), Trevion II, Washington, D. C. 205850002.

68. B. Ross, ASI, European Analytical Services, 1660 L Street NW 314, Washington, D.C. 20036.

69. C. M. Seidel, Westinghouse Hanford Company, P.O. Box 1970, Richland, WA 99352.

70. L. L. To 'o, Westinghouse SRTC, P.O. Box 616, Aiken, SC 29802.

71. J. E. Young, Westinghouse SRTC, P.O. Box 616, Aiken, SC 29802. 
72. Office of Asst. Mgr. Energy Research and Development, DOE Oak Ridge Operations, Oak Ridge, TN 37831.

73-74. Office of Scientific and Technical Information, P. O. Box 62, Oak Ridge, TN 37831 


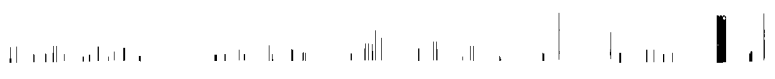
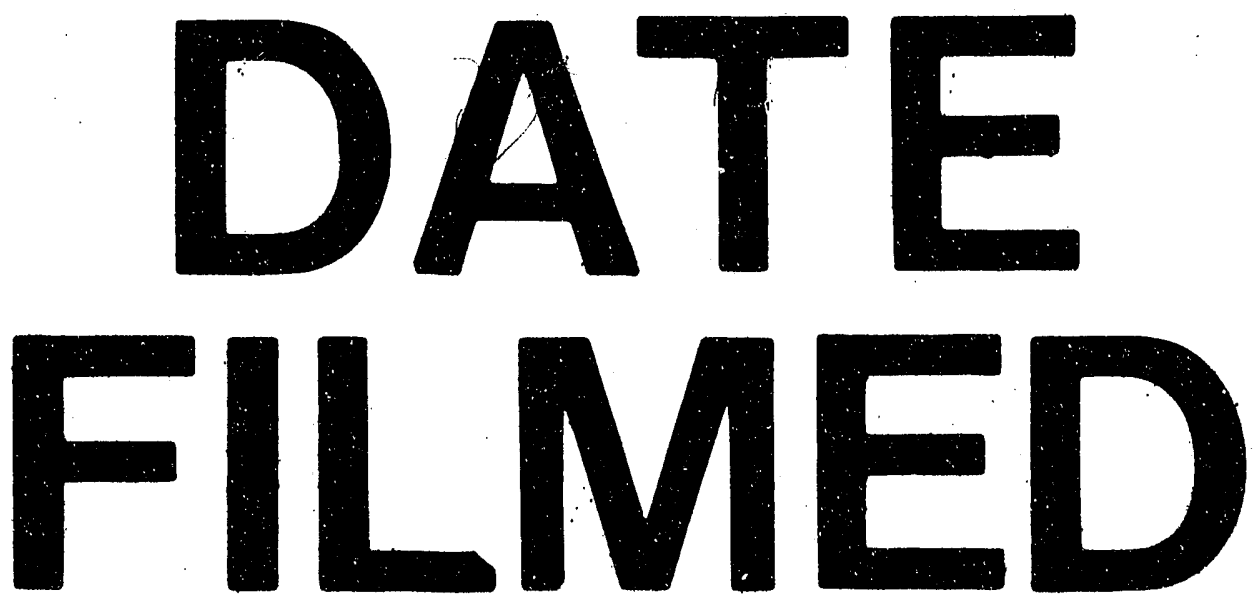

1

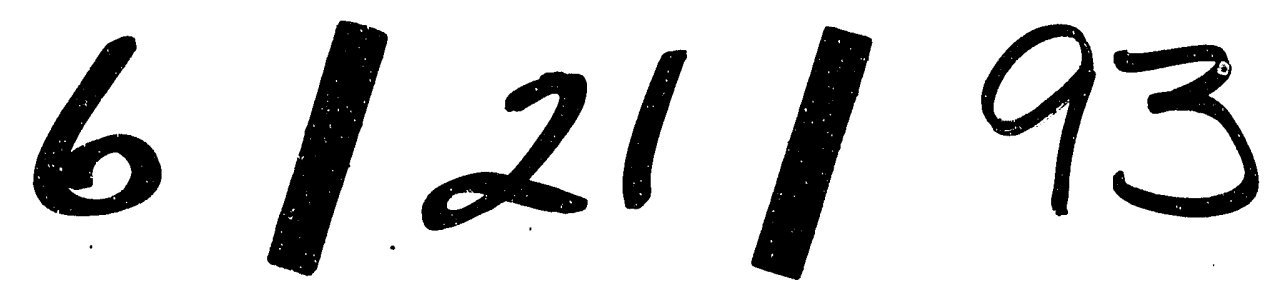




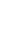

